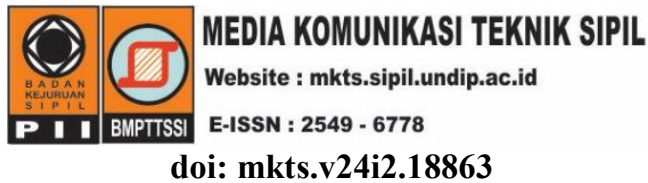

\title{
Sustainability Beton Metode Life Cycle Assessment Studi Kasus: Limbah Beton Laboratorium Bahan dan Konstruksi Departemen Teknik Sipil Universitas Diponegoro Semarang
}

\author{
"Christhy Amalia Sapulete', Han Ay Lie ${ }^{2}$, Yulita Arni Priastiwi ${ }^{2}$ \\ ${ }^{1}$ Institut Sains dan Teknologi Indonesia, Manokwari \\ ${ }^{2}$ Departemen Teknik Sipil, Universitas Diponegoro, Semarang \\ *) christhy.sapulete@gmail.com
}

Received: 7 Mei 2018 Revised: 13 November 2018 Accepted: 15 November 2018

\begin{abstract}
Sustainability is an effort to build an infrastructure by considering the environmental impacts that occur. Concrete production as a construction material that commonly used in infrastructure development is one contributor to carbon dioxide $\left(\mathrm{CO}_{2}\right)$ emissions. $\mathrm{CO}_{2}$ is produced from the calcination process in the manufacture of cement, burning of fossil fuels, and electrical energy used. More specifically by reviewing the calcination process on cement making, it has evaluated the consumption of cement in concrete production. The Life Cycle Assessment (LCA) is an environmental impact evaluation in terms of the life cycle of a product, wherein this paper, using the cradle-to-cradle scope, LCA is used as a method to evaluate cement consumption in concrete production to concrete waste management by taking concrete waste at Construction Laboratory and Materials Diponegoro University, Semarang for the case study. The results of the evaluation stated that the use of geopolymer concrete with fly ash as a substitute for cement could reduce up to $80 \% \mathrm{CO}_{2}$ emissions with concrete strength $75 \%$ larger than conventional concrete. And for the concrete waste management, Construction Laboratory and Materials Diponegoro University reused concrete cylinder waste as a substitute material to build the retaining wall.
\end{abstract}

Keywords: Sustainability, cement consumption, life cycle assessment

\begin{abstract}
Abstrak
Dalam bidang teknik sipil, sustainability merupakan upaya untuk membangun suatu infrastruktur dengan mempertimbangkan dampak lingkungan yang terjadi. Produksi beton sebagai material konstruksi yang umum digunakan dalam pembangunan infrastruktur merupakan salah satu penyumbang emisi karbon dioksida $\left(\mathrm{CO}_{2}\right)$. Karbon dioksida dihasilkan dari proses kalsinasi pada pembuatan semen, pembakaran bahan bakar, serta energi listrik yang digunakan. Lebih spesifik dengan meninjau proses kalsinasi pada pembuatan semen, maka telah dievaluasi konsumsi semen pada produksi beton. Life Cycle Assessment (LCA) adalah evaluasi dampak terhadap lingkungan ditinjau dari siklus hidup suatu produk, dimana dalam penulisan ini, dengan menggunakan ruang lingkup cradle-to-cradle, LCA digunakan sebagai metode untuk mengevaluasi konsumsi semen pada produksi beton hingga manajemen limbah beton dengan mengambil studi kasus limbah beton Laboratorium Bahan dan Konstruksi Universitas Diponegoro Semarang. Hasil evaluasi menyatakan penggunaan beton geopolimer dengan bahan dasar fly ash sebagai pengganti semen dapat mereduksi hingga $80 \%$ emisi $\mathrm{CO}_{2}$ dengan kekuatan beton $75 \%$ lebih besar dibandingkan dengan beton konvensional. Manajemen limbah beton yang dilakukan Laboratorium Bahan dan Konstruksi Universitas Diponegoro Semarang adalah dengan menggunakan kembali limbah silinder beton pada pekerjaan pembuatan retaining wall sebagai pengganti material batu kali.
\end{abstract}

Kata kunci: Sustainability, konsumsi semen, life cycle assessment 


\section{Pendahuluan}

The Global Competitiveness Report 2017-2018 menyatakan indeks infrastruktur Indonesia mengalami kenaikan dan menduduki peringkat ke-52 setelah pada periode sebelumnya berada pada peringkat ke-62. Pembangunan infrastruktur yang terus meningkat di Indonesia harus diimbangi dengan upaya untuk menjaga stabilitas dampak lingkungan yang terjadi. Salah satunya yaitu mengurangi emisi karbon dioksida $\left(\mathrm{CO}_{2}\right)$. Karbon dioksida merupakan salah satu pembentuk gas rumah kaca di atmosfer yang menyebabkan terjadinya efek rumah kaca pada bumi. Berlandaskan pemahaman ini, maka diperlukan suatu pembangunan infrastruktur yang sustainable, yaitu pembangunan yang dapat menghasilkan infrastruktur yang ramah lingkungan.

Dalam buku The Sustainable Use of Concrete, Sakai et al (2013) mengemukakan beberapa sistem evaluasi yang digunakan untuk mengevaluasi sustainability, yaitu Life Cycle Assessment (LCA), Environmental Standards for Building, System of Environmental Impact Evaluation, dan Environmental Standards for Concrete Sectors. LCA merupakan evaluasi input, output dan potensi dampak lingkungan dari suatu produk yang ditinjau dari seluruh siklus hidupnya. Evaluasi dengan LCA dapat mengidentifikasi peluang untuk meningkatkan aspek lingkungan dari produk di berbagai titik dalam siklus hidupnya (Mulyana \& Wirahadikusumah, 2017).

Environmental Standards for Building merupakan evaluasi yang menetapkan metode penilaian pada potensi dampak lingkungan dari konstruksi yang dibangun pada tahap pembangunan. System of Environmental Impact Evaluation merupakan evaluasi berbasis aplikasi. Metode ini mengurangi dampak lingkungan dengan melakukan pendekatan menggunakan sistem aplikasi. Aplikasi yang digunakan didesain untuk memberikan informasi tentang karakter lingkungan secara keseluruhan, namun hanya dapat diaplikasikan pada satu produk dan layanan industri. Environmental Standards for Concrete Sectors merupakan evaluasi dengan membuat desain berdasarkan standar environmental. Dewasa ini beton merupakan material yang umum digunakan dalam pembangunan infrastruktur dan produksinya memiliki dampak yang berbahaya bagi lingkungan. Gambar 1 merupakan gambaran siklus hidup dari beton.

Beton konvensional terbentuk dari campuran agregat kasar dan agregat halus yang direkatkan menggunakan pasta semen. Bahan penyusun beton ini umumnya diperoleh dari proses pertambangan yang memiliki dampak langsung terhadap lingkungan yaitu berkurangnya green area. Dengan meninjau lebih spesifik pada produksi semen, dimana semen dihasilkan dari campuran bahan-bahan alam yang dipanaskan dengan suhu tinggi dan bereaksi membentuk kristal klinker yang kemudian dihaluskan dan menjadi bubuk semen. Proses kalsinasi ini yang menjadi salah satu industri penyumbang emisi karbon dioksida (Atmaja, 2015).

Beton geopolimer merupakan beton yang menggunakan fly ash sebagai pengganti semen, dengan menggunakan tambahan aktivator. Reaksi kimia antara fly ash dengan aktivator inilah yang menggantikan fungsi semen sebagai perekat agregat pada beton. Penggunaan teknologi geopolimer dapat mengurangi sekitar $80 \%$ emisi gas karbon dioksida ke atmosfer yang disebabkan oleh industri semen dan agregat (Davidovits, 1994 dan Wallah, 2014).

Data Laboratorium Bahan dan Konstruksi Universitas Diponegoro Semarang tercatat telah melakukan pengujian pada material-material konstruksi, antara lain uji tekan untuk mengetahui kuat tekan beton. Lebih spesifik pada pengujian material beton, jenis beton yang diujikan di Laboratorium Bahan dan Konstruksi Universitas Diponegoro antara lain, uji tekan pada silinder, kubus, paving, mortar, dan uji lentur pada balok.

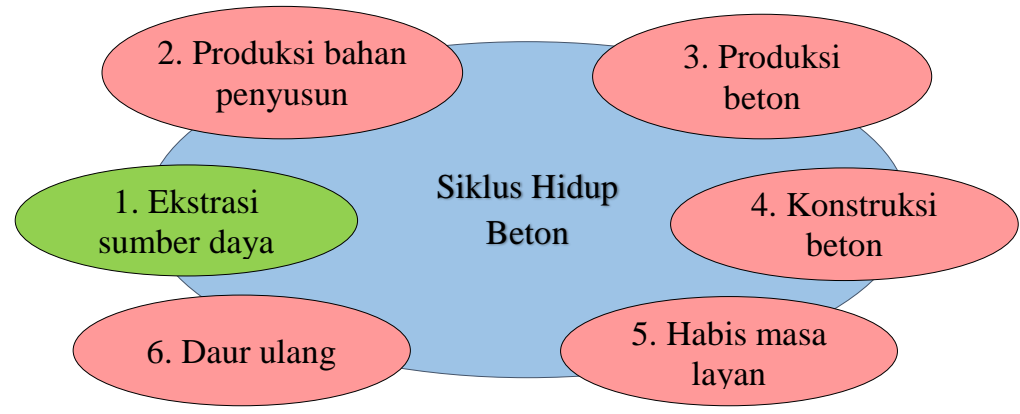

Gambar 1. Siklus hidup beton 
Persentase kubikasi total jenis uji beton yang dilakukan di Laboratorium Bahan dan Konstruksi Universitas Diponegoro Semarang selama 7 tahun terakhir disajikan pada Gambar 2.

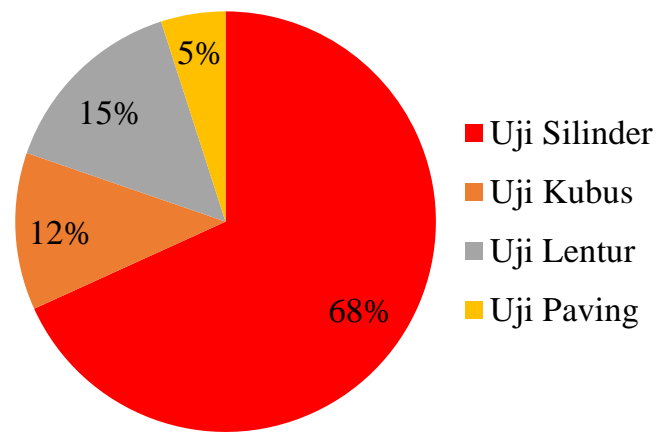

\section{Gambar 2. Data persentase kubikasi total uji beton Laboratorium Bahan dan Konstruksi Universitas Diponegoro Semarang Tahun 2011-2017}

Dalam penulisan ini akan dikaji dampak terhadap lingkungan yang terjadi ditinjau dari penggunaan beton konvensional dalam pekerjaan konstruksi dan evalusinya dengan menggunakan sistem evaluasi LCA yang mengambil studi kasus di Laboratorium Bahan dan Konstruksi Universitas Diponegoro Semarang.

\section{Metode}

Dalam pengembangannya, penulisan paper ini menggunakan metode analisis data dan kajian literatur. Sistem evaluasi LCA mengevaluasi sustainability beton berdasarkan siklus hidupnya dengan meninjau dari proses ekstraksi sumber daya bahan penyusun beton, produksi beton, penggunaan beton sebagai material konstruksi hingga manajemen limbah beton, dimana setiap prosesnya dievaluasi penanganan untuk meminimalisasi dampak terhadap lingkungan. Tahap-tahap analisis dengan menggunakan metode LCA digambarkan pada Gambar 3 (Vertech Group Sarl, 2015).

\section{Global and scope definition}

Global and scope definition merupakan tahapan untuk menentukan ruang lingkup, tujuan dan sistem batasan dalam mengevaluasi menggunakan LCA. LCA memberikan empat tipe ruang lingkup, yang ditunjukkan pada Gambar 4, dalam mengevaluasi sustainability (Marzuki et al., 2013 dan Vertech Group Sarl, 2015), yaitu cradle-tocradle, merupakan analisis yang dimulai dari proses ekstrasi sumber daya alam hingga proses reuse dan recycle; cradle-to-grave, proses analisis dimulai dari ekstrasi sumber daya alam hingga selesai masa layan konstruksi; cradle-to-gate, proses analisis dimulai dari proses ekstrasi sumber daya alam hingga berdirinya suatu konstruksi; gate-to-gate, merupakan analisis LCA terhadap siklus hidup terpendek.

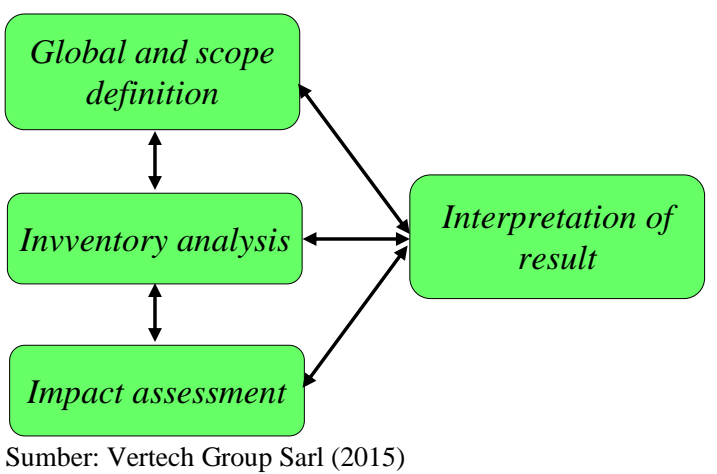

Gambar 3. Tahapan analisis metode LCA

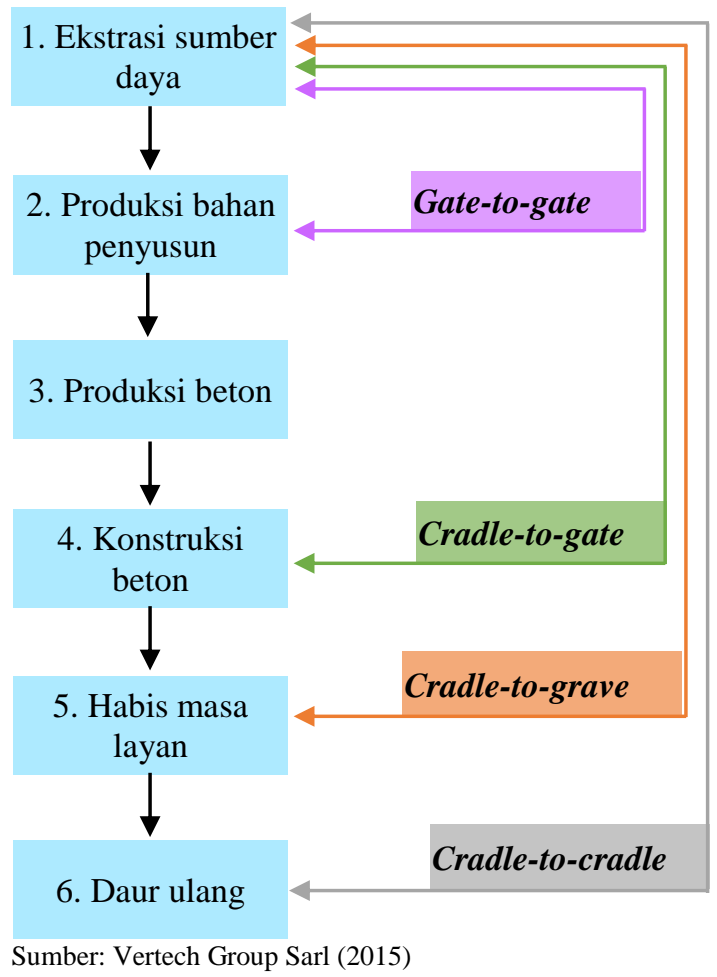

Gambar 4. Ruang lingkup analisis LCA

\section{Inventory analysis}

Dalam inventory analisis, disediakan input data yang akan dianalisis, aliran material dari produk yang ditinjau, dan output hasil akhir yang menjadi kajian evaluasi

\section{Impact assessment}

Tahap ini merupakan tahap evaluasi dampak terhadap lingkungan yang timbul dari tiap siklus hidup yang ditinjau. 


\section{Interpretation of result}

Merupakan tahap akhir dari $L C A$, berisikan simpulan, rekomendasi dan pengambilan keputusan berdasarkan batasan studi dan datadata yang telah dikemukakan pada tahap-tahap sebelumnya.

\section{System boundary}

Dalam tahapan analisis dengan metode LCA diberlakukan system boundary. Pada produksi beton, karbon dioksida dihasilkan antara lain dari proses kalsinasi pada pembuatan semen, proses pembakaran bahan bakar dan penggunaan energi listrik. Dalam paper ini, system boundary hanya membatasi pada evaluasi emisi karbon dioksida yang dihasilkan dari proses kalsinasi pembuatan semen serta evaluasi manajemen limbah beton Laboratorium Bahan dan Konstruksi Universitas Diponegoro Semarang.

\section{Hasil dan Pembahasan}

Hasil analisis serta pembahasan tentang sustainability beton dengan metode LCA pada studi kasus limbah beton Laboratorium Bahan dan Konstruksi Universitas Diponegoro Semarang dijelaskan lebih lanjut dalam poin-poin sebagai berikut:

\section{Global and scope definition}

Produksi semen sebagai salah satu bahan penyusun material beton, merupakan satu dari sekian jenis industri penyumbang emisi gas rumah kaca karena proses kalsinasi pada pembuatan semen menghasilkan banyak karbon dioksida $\left(\mathrm{CO}_{2}\right)$.

Khusus di Indonesia, terdapat banyak konstruksi yang menggunakan beton sebagai material utama sehingga produksi semen pun semakin meningkat untuk memenuhi kebutuhan konsumsi konstruksi beton. Knoema World Data (2016) menyajikan data produksi emisi $\mathrm{CO}_{2}$ yang disumbangkan oleh Indonesia pada Tahun 2016 adalah sebesar 2,03 ton, dimana salah satunya bersumber dari proses pembuatan semen.

\section{Inventory analysis}

Berdasarkan data dari Laboratorium Bahan dan Konstruksi Universitas Diponegoro Semarang, diketahui rata-rata mutu beton yang diuji adalah $35 \mathrm{MPa}$. Dengan perhitungan mix design menggunakan standar dari American Concrete Institute (ACI), pada $1 \mathrm{~m}^{3}$ beton $35 \mathrm{MPa}$ diperoleh volume komposisi bahan penyusun, yakni agregat, semen dan air masing-masing ditunjukkan pada Gambar 5.

Pada Gambar 6 menunujukkan data volume limbah beton dari Laboratorium Bahan dan Konstruksi Universitas Diponegoro Semarang selama kurun waktu 2011-2017

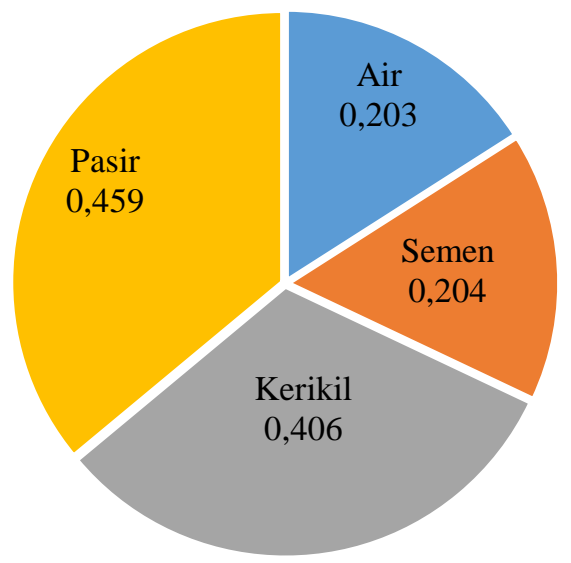

\section{Gambar 5. Volume komposisi bahan penyusun beton mutu $35 \mathrm{MPa}$ dengan mix design metode $\mathrm{ACl}$.}

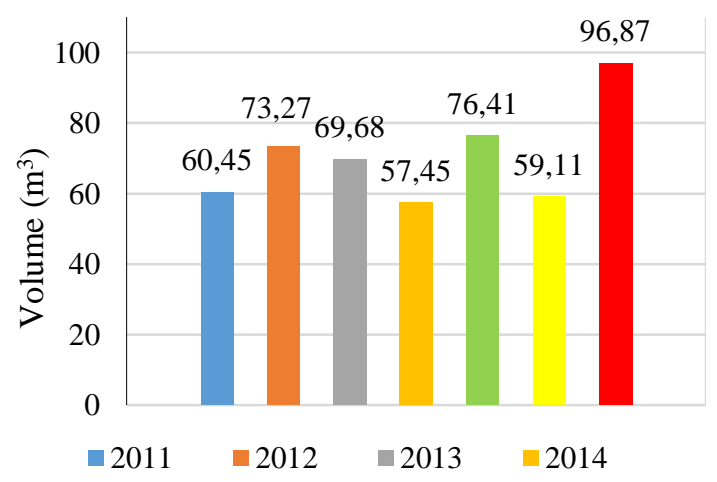

Gambar 6. Data volume limbah beton Laboratorium Bahan dan Konstruksi Universitas Diponegoro Semarang Tahun 2011-2017

\section{Impact assessment}

Hasil perhitungan mix design metode ACI, dibutuhkan $0,204 \mathrm{~m}^{3}$ semen untuk membuat $1 \mathrm{~m}^{3}$ beton mutu $35 \mathrm{MPa}$. Pada Gambar 7 menunjukkan grafik yang menyatakan peningkatan mutu beton terhadap konsumsi semen. Dimana hal ini berarti bahwa semakin tinggi mutu beton, semakin besar pula konsumsi semen yang digunakan.

Dalam Gambar 8 disajikan data konsumsi semen hasil limbah beton serta emisi $\mathrm{CO}_{2}$ yang dihasilkan akibat proses kalsinasi Laboratorium 
Bahan dan Konstruksi Universitas Diponegoro Semarang Pada Tabel 1 diperoleh nilai emisi karbon dioksida $\left(\mathrm{CO}_{2}\right)$. Nilai tersebut dihitung dengan menggunakan rumus, pada Persamaan (1), dengan pendekatan sebagai berikut (Damayanti \& Lestari, 2011):

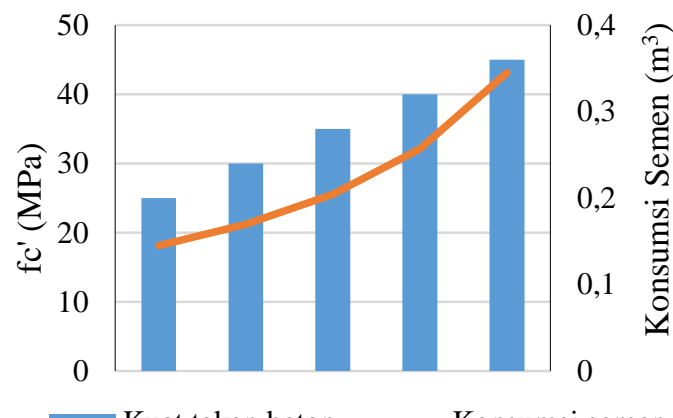

Kuat tekan beton $\longrightarrow$ Konsumsi semen

\section{Gambar 7. Grafik peningkatan kuat tekan beton terhadap konsumsi semen}

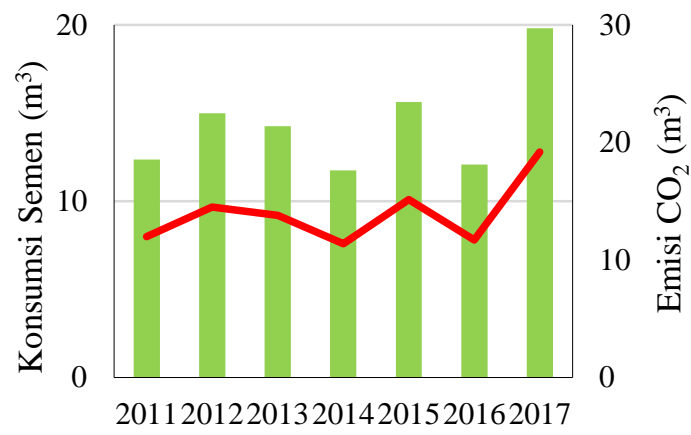

Konsumsi semen $\longrightarrow$ Emisi karbon dioksida

Gambar 8. Data konsumsi semen dan emisi $\mathrm{CO} 2$

Emisi $\mathrm{CO}_{2}=\mathrm{V}_{\text {semen }} \times \mathrm{C}_{\text {klinker }} \times \mathrm{EF}_{\text {klinker }}$

Dimana Emisi $\mathrm{CO}_{2}$ merupakan Emisi $\mathrm{CO}_{2}$ dari produksi semen $\left(\mathrm{m}^{3}\right), \mathrm{V}_{\mathrm{se}}$ merupakan Volume konsumsi semen $\left(\mathrm{m}^{3}\right), \mathrm{C}_{\text {klinker }}$ merupakan Fraksi klinker dalam semen, $\mathrm{EF}_{\text {klinker }}$ merupakan Faktor emisi klinker dalam semen.

Damayanti \& Lestari (2011) memberikan penjelasan nilai default faktor emisi dari produksi klinker $\left(\mathrm{EF}_{\text {klinker }}\right)$ adalah 0,51 ton $\mathrm{CO}_{2}$ per ton klinker. Faktor emisi ini perlu dikoreksi dengan adanya cement kiln dust (CKD) dengan faktor koreksi CKD adalah 2\% dan nilai untuk fraksi klinker $\left(\mathrm{C}_{\text {klinker }}\right)$ adalah $95 \%$ berdasarkan pedoman yang dikeluarkan oleh Kementerian Lingkungan Hidup (2012).

Contoh perhitungan:

Data limbah beton Tahun 2017 adalah 19,81 $\mathrm{m}^{3}$. Faktor emisi masing-masing $\mathrm{C}_{\text {klinker }}=0,152 \times 2=$
1,02 dan $\mathrm{EF}_{\text {klinker }}=95 \%$, sehingga emisi $\mathrm{CO}_{2}$ Tahun 2017 adalah $19,81 \mathrm{~m}^{3} \times 1,02 \times 95 \%=$ $19,19 \mathrm{~m}^{3}$

Tabel 1. Data konsumsi semen dan emisi $\mathrm{CO}_{2}$ tiap tahun berdasarkan data limbah Laboratorium Bahan dan Konstruksi Universitas Diponegoro Semarang

\begin{tabular}{ccc}
\hline Tahun & $\begin{array}{c}\text { Volume } \\
\left(\mathbf{m}^{\mathbf{3}}\right)\end{array}$ & $\begin{array}{c}\text { Emisi } \mathbf{C O}_{\mathbf{2}} \\
\left(\mathbf{m}^{\mathbf{3}} \mathbf{)}\right.\end{array}$ \\
\hline 2011 & 12,36 & 11,98 \\
2012 & 14,98 & 14,52 \\
2013 & 14,25 & 13,81 \\
2014 & 11,75 & 11,38 \\
2015 & 15,63 & 15,14 \\
2016 & 12,09 & 11,71 \\
2017 & 19,81 & 19,19 \\
\hline
\end{tabular}

Dengan peningkatan konsumsi semen, maka semakin meningkat pula produksi gas $\mathrm{CO}_{2}$. Produksi semen sendiri memberikan banyak dampak terhadap lingkungan. Gas rumah kaca terbentuk karena adanya peningkatan konsentrasi gas $\mathrm{CO}_{2}$ dan gas-gas lainnya di atmosfer. Alaminya, bila produksi gas $\mathrm{CO}_{2}$ pada batas yang wajar tidak menimbulkan bahaya karena $\mathrm{CO}_{2}$ dibutuhkan untuk membantu tumbuhan hijau melakukan fotosintesis. Namun meningkatnya produksi gas $\mathrm{CO}_{2}$ secara berlebihan melebihi kemampuan tumbuhan untuk menyerapnya. Salah satunya penyumbang emisi $\mathrm{CO}_{2}$ bersumber dari proses kalsinasi pada pembuatan semen dan berkurangnya green area karena proses penambangan sumber daya alam menyebabkan berkurangnya proses penyerapan $\mathrm{CO}_{2}$.

Disisi lain ditinjau pula limbah beton sisa dari pengujian di Laboratorium Bahan dan Konstruksi Universitas Diponegoro Semarang, seperti ditampilkan pada Gambar 9. Dengan limbah beton yang menumpuk menyebabkan terjadinya pencemaran tanah dan pencemaran udara akibat debu dari limbah beton.

\section{Interpretation of result}

Berdasarkan data, dapat disimpulkan dua hal sebagai interpretation of result, yaitu bahwa konsumsi semen bergantung pada tingkat kebutuhan beton sebagai material konstruksi dan dengan meningkatnya kebutuhan konstruksi beton, semakin meningkat pula konsumsi semen yang menyebabkan peningkatan produksi karbon dioksida $\left(\mathrm{CO}_{2}\right)$. Uji beton yang dilakukan di Laboratorium Bahan dan Konstruksi Universitas Diponegoro Semarang tiap tahunnya mengalami peningkatan juga penurunan, namun dengan peningkatan dan penurunan konsumsi semen (Gambar 10), emisi $\mathrm{CO}_{2}$ terus meningkat dan 
terkonsentrasi di atmosfer, sehingga terus menambah produksi gas rumah kaca.

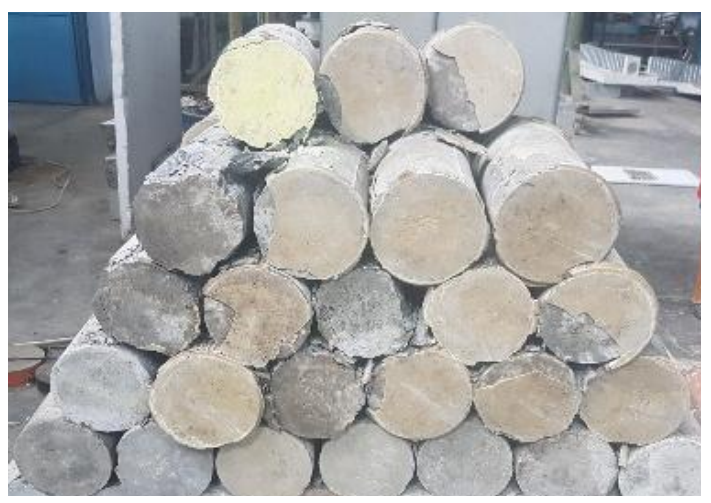

a. Limbah uji tekan silinder beton

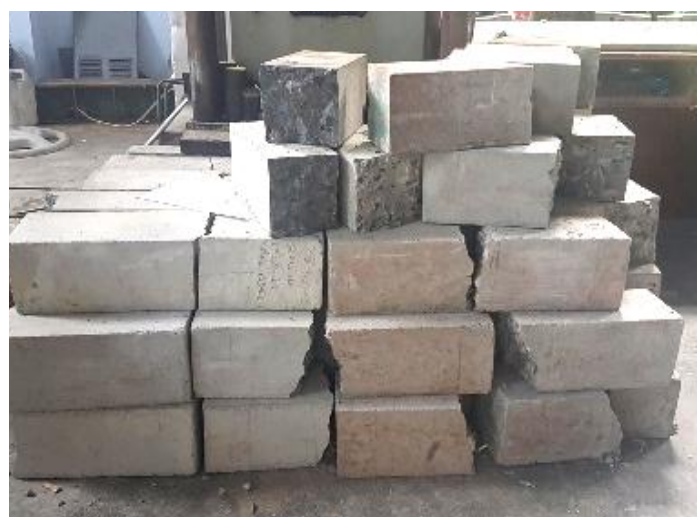

b. Limbah uji lentur

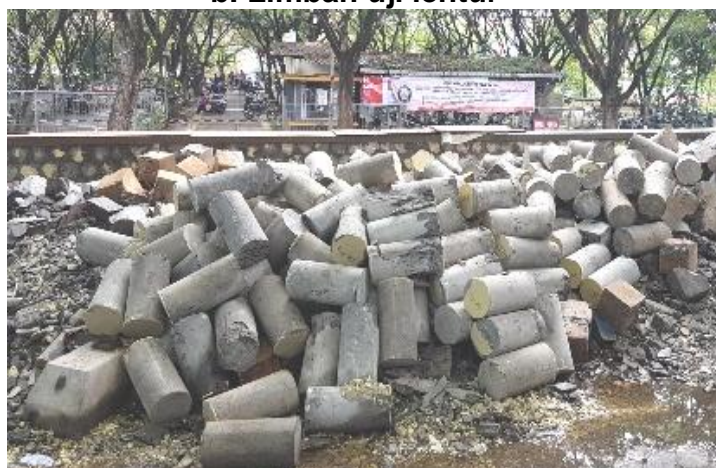

c. Penumpukan limbah silinder beton

Gambar 9. Limbah beton Laboratorium Bahan dan Konstruksi Universitas Dipnegoro Semarang (dokumentasi 28 Maret 2018)

a. Fly ash sebagai pengganti semen

Berangkat dari masalah lingkungan yang timbul akibat konsumsi semen, maka menghasilkan beton yang sustainable menjadi suatu kewajiban pada masa kini untuk meminimalisir dampak lingkungan yang terjadi. Salah satu inovasi yang dikembangkan beberapa tahun terakhir adalah pembuatan beton geopolimer.
Pasta geopolimer diperoleh dari pengikatan akibat reaksi kimia yang terjadi pada pencampuran fly ash dengan aktivator. Berdasarkan penelitian terdahulu yang dilakukan oleh Ekaputri \& Triwulan (2013) dan Mulyana \& Yolanda (2017),

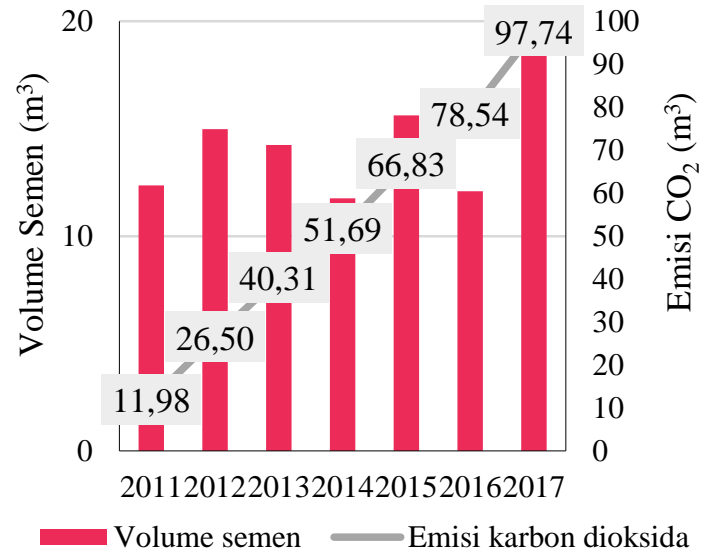

Gambar 10. Grafik peningkatan emisi $\mathrm{CO}_{2}$ Tahun 2011-2017

Farizka \& Darma (2018) melanjutkan penelitian dengan membuat studi eksperimental pengaruh aktivator pada beton geopolimer berbahan dasar fly ash tipe F, yang berasal dari sisa pembakaran batu bara, dengan komposisi larutan aktivator dan fly ash adalah 0,65:0,35. Larutan aktivator yang digunakan adalah sodium hidroksida $(\mathrm{NaOH})$ dan sodium silika $\left(\mathrm{Na}_{2} \mathrm{SiO}_{3}\right)$ dengan komposisi berturut-turut 1:2 (Gambar 11). Komposisi mix design pada beton geopolimer dan beton konvensional, yaitu proporsi agregat pada kedua beton adalah $70 \%$, proporsi semen pada beton konvensional sama dengan fly ash pada beton geopolimer, yaitu $19,5 \%$, serta proporsi air pada beton konvensional sama dengan larutan aktivator pada beton geopolimer, yaitu 10,5\%. Dengan komposisi tersebut diperoleh hasil kuat tekan beton geopolimer lebih besar dibandingkan dengan beton konvensional.

Salah satu faktor penentu dalam penggunaan fly ash sebagai pengganti semen adalah tingkat konsentrasi larutan aktivator atau yang disebut dengan molaritas. Penelitian terdahulu dilakukan oleh Ekaputri dan Triwulan (2013), menyatakan bahwa nilai kuat tekan beton dipengaruhi oleh besarnya molaritasnya larutan aktivator. Berdasarkan studi eksperimental dari penelitian terdahulu, diketahui bahwa komposisi $\mathrm{NaOH}$ dan $\mathrm{Na}_{2} \mathrm{SiO}_{3}$ berturut-turut 1:2 dinilai sebagai komposisi yang ideal untuk digunakan. Komposisi ini dianggap ideal karena jika konsentrasi molar yang digunakan semakin ditingkatkan lagi, maka semakin kental larutan yang dihasilkan dan semakin sulit pengerjaannya (workability). 


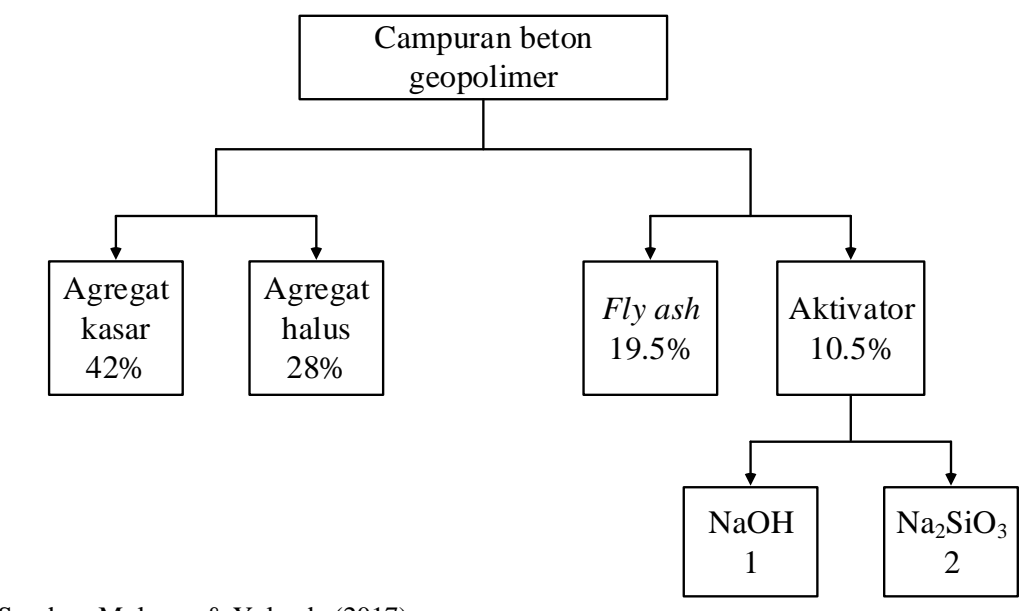

Sumber: Mulyana \& Yolanda (2017)

\section{Gambar 11. Mix design beton geoplimer}

Dalam pengujiannya, Farizka \& Darma (2018) juga menjelaskan bahwa beton geopolimer memiliki setting time dan final setting yang lebih lama dibanding dengan beton konvensional, sehingga pada umur awal peningkatan kuat tekan beton lebih tinggi dibanding beton geopolimer. Namun saat umur 28 hari, kuat tekan beton geopolimer mencapai $75 \%$ lebih besar dibandingkan dengan beton konvensional.

Berdasarkan pengujian-pengujian yang telah dilakukan pada beton geopolimer dengan hasil kuat tekan yang lebih tinggi dibandingkan dengan beton konvensional, sehingga menjadi perhatian khusus dalam mempertimbangkan penggunaan beton geopolimer dalam pembangunan konstruksi beton di Indonesia.

b. Manajemen limbah beton di Laboratorium Bahan dan Konstruksi Universitas Diponegoro Semarang

Dengan menggunakan ruang lingkup cradle-tocradle sebagai standar evaluasi LCA, maka ditinjau pula upaya daur ulang limbah beton. Laboratorium Bahan dan Konstruksi Universitas Diponegoro Semarang melakukan inovasi dalam mengelola limbah beton. Benda uji silinder beton, salah satu jenis beton yang diujikan di Laboratorium Bahan dan Konstruksi Universitas Diponegoro Semarang, sebagai limbah beton kemudian digunakan kembali (reuse) sebagai material pengganti batu kali untuk membuat retaining wall di lingkungan Laboratorium Struktur dan Bahan Universitas Diponegoro Semarang (Gambar 12). Penggunaan kembali limbah beton juga meningkatkan nilai ekonomis dari pekerjaan retaining wall. Dengan upaya reuse, konsumsi batu kali yang diperlukan untuk pekerjaan retaining wall dapat digantikan beton silinder sebagai bentuk manajemen limbah beton yang dilakukan oleh Laboratorium Bahan dan Konstruksi Universitas Diponegoro Semarang.

\section{Kesimpulan}

Dengan menggunakan data limbah dari Laboratorium Bahan dan Konstruksi Universitas Diponegoro Semarang, diperoleh hasil bahwa konstruksi beton yang sustainable, dapat dihasilkan dengan menggunakan beton geopolimer sebagai bahan konstruksi untuk menggantikan beton konvensional. Tidak hanya menggantikan bahan dasar pada beton yang menjadikannya sustainable, namun upaya untuk mendaur ulang limbah beton juga diperlukan. Limbah beton yang dapat dimanfaatkan dan dikelola dengan baik dapat pula meminimalisasi dampak lingkungan yang terjadi karena dapat menekan industri penambangan yang menjadi penyebab hilangnya green area. Dalam hal ini limbah beton Laboratorium Bahan dan Konstruksi Universitas Diponegoro Semarang melakukan reuse limbah beton silinder sebagai material untuk pekerjaan pembuatan retaining wall menggantikan material batu kali yang biasanya digunakan pada pekerjaan pembuatan retaining wall.

\section{Ucapan Terima Kasih}

Ucapan terima kasih ditujukan kepada Kepala Laboratorium Bahan dan Konstruksi Universitas Diponegoro Semarang beserta laboran dan pegawai, atas kerjasama dan kepercayaannya kepada penulis sehingga penulisan paper ini dapat selesai dengan baik dengan menggunakan pada data limbah beton Laboratorium Bahan dan Konstruksi Universitas Diponegoro Semarang. 


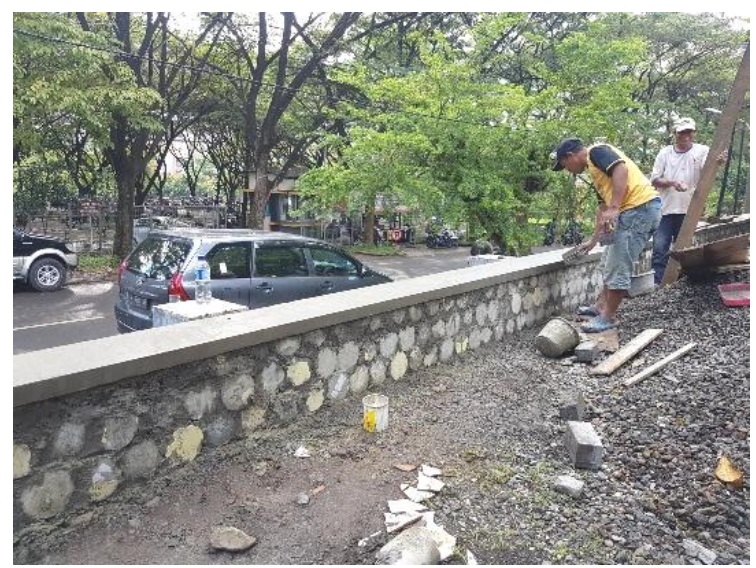

(a). Pekerjaan pembuatan retaining wall

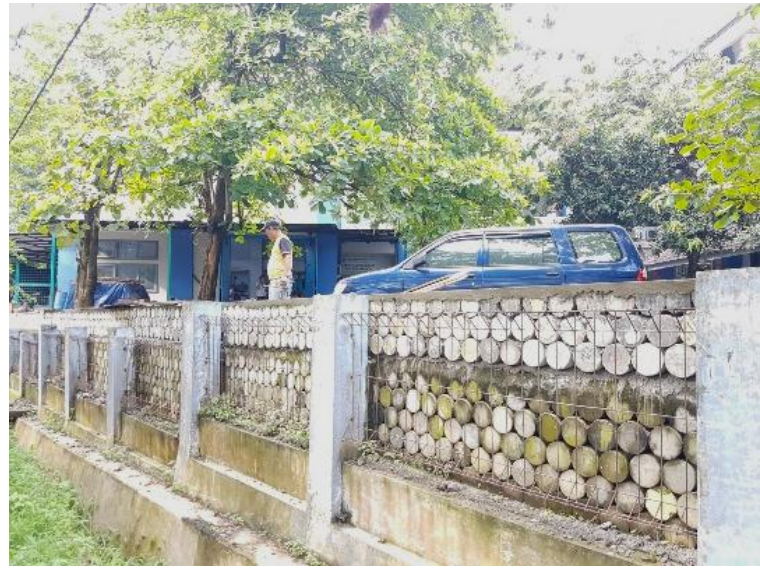

(b). Retaining wall dengan menggunakan limbah silinder beton

Gambar 12. Reuse limbah beton silinder sebagai material pembuat retaining wall di lingkungan Laboratorium Bahan dan Konstruksi Universitas Diponegoro Semarang (dokumentasi 28 Maret 2018)

\section{Daftar Pustaka}

Atmaja, I. G. D. (2015). Industri Semen dan Emisi Carbon Dioxude $\left(\mathrm{CO}_{2}\right)$ di Pulau Jawa. Media Bina Ilmiah, 9(2), 63-65.

Damayanti, S., \& Lestari, P. (2011). Inventarisasi Emisi $\mathrm{CO}_{2}$ dari Proses Kalsinasi pada Industri Semen di Indonesia Berdasarkan IPCC Guidelines 2006. Program Studi Teknik Sipil dan Lingkungan. Institut Sains dan Teknologi Bandung. 1-12.

Davidovits, J. (1994). High-alkali Cements for $21^{\text {st }}$ Century Concretes. ACI Concrete International, 144, (383-397)

Ekaputri, J. J., \& Triwulan. (2013). Sodium sebagai Aktivator Fly Ash, Trass dan Lumpur Sidoarjo dalam Beton Geopolimer, 20(1), 1-10. Farizka, \& Darma. (2018). Studi Experimental Pengaruh Perbedaan Molaritas. Jurnal Karya Teknik Sipil, 7, 89-98.

Kementerian Lingkungan Hidup. (2012). Pedoman penyelenggaraan inventaris gas rumah kaca nasional, metodologi penghitungan tingkat emisi gas rumah kaca proses industri dan penggunaan produk (IPPU). Jakarta: Kementrian Lingkungan Hidup.

Knoema World Data. Indonesia- $\mathrm{CO}_{2}$ Emissions per Capita. (2016).
Marzuki, P. F., Abduh, M., \& Driejana, R. (2013). Peran Life Cycle Analysis (LCA) pada Material Konstruksi dalam Upaya Menurunkan Dampak Emisi Karbon Dioksida pada Efek Gas Rumah Kaca. Konferensi Nasional Teknik Sipil 7 (KoNTekS 7), Universitas Sebelas Maret, Surakarta.

Mulyana, A., \& Wirahadikusumah, D. R. (2017). Analisis Konsumsi Energi dan Emisi Gas Rumah Kaca pada Tahap Konstruksi Studi Kasus : Konstruksi Jalan Cisumdawu. Jurnal Teknik Sipil ITB. ISSN No. 0853-2982, 24(3), 269-280.

Mulyana, F., \& Yolanda, T. (2017). Studi Properties Beton Geopolimer Sebagai Subtitusi Beton Konvensional. Skripsi, Semarang: Universitas Diponegoro.

Sakai, Koji, \& Noguchi, Takafumi. (2013). The sustainability use of concrete. CRC Press.

The Global Competitiveness Report The Global Competitiveness Report 2017-2018. (2017). World Economic Forum, 5.

Vertech Group Sarl. (2015). LCA scope and analysed system boundaries definition of limits and functional Units. LCA Preparation.

Wallah, S. E. (2014). Pengaruh Perawatan dan Umur terhadap Kuat Tekan Beton Geopolimer Berbasis Abu Terbang. Jurnal Ilmiah Media Engineering, 4(1), 1-7. 